\title{
Developing a Research Framework: Lessons from Malaysia's Hotel Industry
}

\author{
Yashidevan Saththasivam \\ School of Management Asia E University \\ 5000, Wilayah Persekutuan Kuala Lumpur, Malaysia \\ Yashidevan@gmail.com
}

\author{
Dr. Mohammad Yazam Sharif \\ School of Management University Utara Malaysia \\ 06010, Sintok, Kedah, Malaysia \\ Yazamsharif@gmail.com
}

\begin{abstract}
-this research attempts to analyze the effect of employee motivation on work performance in hotels in Malaysia. The elements used under employee motivation are pay, job security, working environment, career development and recognition. Work performance is the dependent variable whereas employee motivation is the independent variable. The purpose of conducting the research is to solve the research problem, which is employees are the most important factor in the hotel industry. The services offered by employees are the reason for tourist to continue to flood the country. In order for employees to continue offering good services, factors that can keep them motivated to perform are of utmost important. The government realizes the importance of 'people' and concerns were raised about whether the hotel industry will be able to retain talents and obtain good work performance through attractive salaries. Therefore, this research is undertaken to understand the influence of employee motivation on work performance and to understand this. This research intends to identify the factors that have effect on work performance
\end{abstract}

Keywords-job security; recognition; career development, training, work performance.

\section{INTRODUCTION}

Malaysia is known as popular tourist destinations in Asia. According to the Ninth Malaysian plan, RM1367 million has been allocated for the tourism industry because the industry is seen to have the potential to contribute to the service sector and also to the economy of the country [1]. The hotel sector plays an important role in the tourism industry. Past statistics has indicated that the hotel sales volume represents approximately $36 \%$ of the total receipts from tourism [2]. The researcher believes that employees are the main contributors to the service industry and along with that their motivation plays significant role in improving the performance of the hotel industry. An article in Star Newspaper shares that employees are the ones who work behind the scenes in the hotels' daily operations and are responsible for the success of the hotel industry in Malaysia [3]. This displays the importance of human factor in the hotel industry.

In today's competitive world, the high-performance workforce is a major source for success. Whether organizations are small or large, success depends on how well they utilize their people's capabilities to achieve the organization's vision, goals, and objectives. Living in a knowledge economy, the core assets of the modern business enterprise aren't its buildings, machinery, and real estate but intelligence, understanding, skills and experience of its employees.

In the hotel industry which is, after all, a people-oriented service - the abilities, behavior, and attitudes of the employees have become the very cornerstone of the business, especially in these competitive times. Therefore, it is strongly believed that employee motivation plays a pivotal role in improving an organization's performance which can then be translated into a competitive advantage. Thus, this research aims at investigating the five-key influences or factors which constitute to motivation in the context of hotels in Malaysia and its impact on the work performance.

Identifying factors that motivate employees is often a challenge faced by most managers. Along with that, given the constant pressure instilled by the Malaysian government to make Malaysia the best tourist spot further presses the hotel industry. Therefore, considering both factors the researcher realizes the need to conduct a study in the area of employee motivation so that a contribution can be made to the management of the hotels in Malaysia on the motivational factors. This eventually can contribute towards achieving optimum level of performance for the betterment of the industry which would eventually help in realizing the expectation of the Malaysian government. 


\section{BACKGROUND OF STUDY}

The purpose of this study is to understand the effect of employee motivation on work performance in Malaysia Hotel industry and to identify the factors that contribute to employee motivation in delivering their best in the organization. Specifically, the study sought to describe the importance of the following five motivating factors: (a) pay, (b) job security, (c) working conditions, (d) career development, and (e) recognition. The variables have been replicated from a study conducted by Dr. Kovach on the hospitality industry which found the variables as the top most important motivating factors for employees [4]. Therefore, the same variables would be adopted for this study in the context of in Malaysia Hotel industry.

\section{Problem Statement}

Human resource is an area that is growing in importance as organizations are greatly focusing on employees and their roles as service providers. Conditions, attitudes, and expectations that prevailed before the Industrial Revolution were greatly different from the current working environment given social, technological and economic changes. [5] Reports that the people factor remains the key to the tourism sector. Concerns are raised about whether the hotel industry will be able to retain talents and obtain good work performance through attractive salaries. The question is whether the attractive salary is the only way to motivate employees? [6] Shares that employees' look for benefits and extras from their employers. It is undeniable that attractive salaries are important but other benefits and extras are equally essential which need to be identified and fulfilled accordingly in order to obtain good performance and retain talented employees in this promising industry.

[5] Further reports that though low hotel rates, airfares and travel packages contribute towards attracting tourist into the country but 'the people factor' is given greater importance in attempting to make the country the top tourist destinations in the world. Talented and skilled personnel are the key ingredient for the success of the industry.

The service industry is generally accepted as a laborintensive industry, therefore there is a need to tackle the importance of labor retention in this industry. This has become one of the major issues in Asia and Malaysia. The hotel industry in Malaysia is facing shortages of the local labor force. Most locals work abroad in countries like Singapore, Hong Kong, Macau, Dubai, Europe, Mainland of China and the Middle East where the wages are more attractive [7]. Over the years, there has been a shortage in the hotel industry and, as a result, some management of the hotels has opted to hire foreign workers to fill in the front liners position, this has resulted in not creating an original Malaysian identity, [8]. Hotel operators had little choice but to hire foreigners since locals did not want to work in hotels. Foreigners are not their priority to be hired but if locals do not take up these jobs then there would be no sufficient employees to cover these jobs. In order to satisfy the need for the hotel staffs, managements are looking at hiring English speaking staffs from other countries. Countries like the Philippines are targeted for some as they have good English backgrounds. [7]. This has resulted in over dependency towards foreign staffs.

Summary of the Research Problems are as follow:

I. Shortage of local labor force.

II. Malaysia is highly dependent on foreign workers in the service industry.

III. Locals refuse to work in Hotels.

IV. What are the factors that motivate employees?

\section{RESEARCH PURPOSE}

Given constant importance on the human factor, the findings from this research would provide useful inputs to the management of hotels in Malaysia on the motivational factors that can contribute towards improved work performance. This study is intended to evaluate the factors that motivate employees in the Malaysia Hotel industry. It would help to realize the importance of effective employee motivation and its effect on employees' work performance. The researcher also believes that the findings of this research would greatly contribute to the tourism industry, given the government's constant effort of making Malaysia a famous tourism spot. The government has recognized the importance of the workforce of the hotel industry and the findings of this research would offer great inputs on ways to keep the workforce motivated for improved performance.

The summary of research objectives of this study are as follows:

I. To investigate the influence of employee motivation on work performance in Malaysia Hotel industry.

II. To identify the most important factor that motivates employees in Malaysia Hotel industry.

III. To propose solutions to improve employee motivation in Malaysia Hotel industry towards improving work performance.

\section{Research ObJective}

What is the motive behind employees leaving or quitting their work and moving away from their establishment or company? Turnover is a natural aspect in the hotel Industry that happens. Turnover happens when there is dissatisfaction in the job. Job motivations are a set attitude towards work and job motivation is required by all staffs or employees. Job motivation affects turnover, absenteeism and performance. Employees that are more satisfied with their jobs or works are less absent and would stay on longer in their jobs compared to the least satisfied employees. Job satisfaction is determined by a variety of factors, the work itself, wages or salaries, growth and upward mobility, supervision, colleagues and attitude towards work [9]. 
The summary of research questions of this study are as follows:

I. What influence employee motivation towards work performance in the hotels in Malaysia?

II. Which factor is most important that motivates employees in the Hotel Industry in Malaysia?

III. What steps to undertake to improve employee motivation in the hotels in Malaysia towards improving work performance?

IV. How does motivation impact an employee's productivity?

\section{LITERATURE REVIEW}

The researcher believes that employee motivation is one of the main issues faced by most industries in Malaysia. This is supported by [10] who shares that issue of staff retention and job motivation continues to plague organizations in Malaysia. Annual surveys by Malaysian Employers Federation reports that the annual labor turnover rates for 2003 and 2004 were high.

However, the researcher strongly believes that employee motivation has an effect on work performance in Malaysia Hotel industry. This is in line with the study by [11] on motivation and its impact on job performance which discovered that the key to improve performance and productivity in any area or endeavor is motivation rather than ability. Since hotel industry focuses on service performance, this requires employees' effort to undertake their task and effort is what motivation is about. Along with the knowledge, skills, and attitude, motivation plays an equally important role. Managers are not only responsible for providing employees with the adequate knowledge and skills but also need to have the skills to motivate employees for the benefit of the organization and industry.

[12] Shares that if there is one thing that can be learned about motivating the workforce of an organization, it's that one size that definitely does not fit all. Taking into consideration that all employees are not motivated in the same way, studies both in and out of the hotel industry have investigated the importance of offering diverse incentives and creative management strategies for motivating employees. As said by Napoleon Bonaparte, "Give me enough medals and I'll win you any war". Therefore, this section of the study would like to bring forward several studies that have been conducted on the variables.

\section{A. Motivation}

Hundreds of definitions exist for the term motivation, however, the researcher believes that motivation is fundamental to human behavior. [13] Defines motivation as a process of uncovering needs and realizing them. He stressed that the role of management is to identify such needs and meets them to motivate staff. Similarly, [14] says that employee's motivation is the 'willingness to exert a high level of inspiration to reach organizational goals, conditioned by the effort's ability to satisfy individual need'. This indicates that motivation encourages an employee to perform and the willingness to perform only comes when they believe that their effort would lead to a need of satisfaction.

Elton Mayo had conducted a study during the year of 1924 and 1932 which changed the perception of employees. The research known as the Hawthorne Studies revealed that employees required more than just money. The study brought the human relations element into organizations with a main focus on the requirements of employees and their motivation. This brought intrinsic and extrinsic motivators. Intrinsic motivation is defined as the enjoyment that a person feels by achieving the task and it is driven by factors that people perceive that they can control themselves, based on their level of commitment and amount of effort. Extrinsic motivation comes from outside of the person and can be either from positive influences such as tangible incentives and recognition that are awarded for task achieved, or negative, such as the fear of punishment or ridicule for a task not achieved [15].

The researcher strongly believes that intrinsic motivation has stronger impact on employee motivation as it highly relates to employee feelings. This can be supported by a research conducted by [16] on 400 organizations revealing that intrinsic motivation positively relates to employee turnover. The study revealed that turnover intention was only positive for employees whose intrinsic motivations were low. Further to this, [17] confirms this through a study on employee motivation and performance in the fast food and hotel industries revealing that higher levels of employee motivation is translated into a 53 percentage reduction in worker turnover. This greatly indicates the importance of organizations providing intrinsic motivation which the researcher highly supports. Similarly, [18] shares that in hotels, intrinsic motivation is an important indicator of productivity. This research would provide an additional insight on the importance of intrinsic motivation in the context of Malaysia Hotel industry.

[19] supported the importance of intrinsic rewards. It was stressed that when employees feel good about work, it means that employees are doing something worthwhile (meaningfulness), being able to do something the way employees think it should be done (choice), performing activities particularly well (competence) and making a significant advancement towards accomplishing a purpose (progress). This was categorized into four intrinsic rewards illustrated in Figure 1. 


\begin{tabular}{|c|c|c|}
\hline OPPORTUNITY & $\begin{array}{r}\text { RTUNITY } \\
\text { Rewards } \\
\end{array}$ & $\begin{array}{c}\text { ACCOMPLISHMENT } \\
\text { Rewards } \\
\end{array}$ \\
\hline $\begin{array}{c}\text { From Task } \\
\text { ACTIVITIES }\end{array}$ & Sense of CHOICE & $\begin{array}{c}\text { Sense of } \\
\text { COMPETENCE }\end{array}$ \\
\hline $\begin{array}{l}\text { From Task } \\
\text { PURPOSE }\end{array}$ & $\begin{array}{c}\text { Sense of } \\
\text { MEANINGFULNESS }\end{array}$ & $\begin{array}{c}\text { Sense of } \\
\text { PROGRESS }\end{array}$ \\
\hline
\end{tabular}

Given the right level of motivation, the researcher believes that organizations can experience a great deal of operational effectiveness. This is in line with [15] saying that motivated employees help organizations survive. Motivated employees are needed in rapidly changing workplaces as they are seen to be more productive. As much as employees contribute to organizations' performance, the researcher believes that it is equally essential to take note of employees' goals and ensure that it is in line with the company goals. This is supported by a research by [20] arguing that motivation plays an important role in achieving goals and business objectives and for this to happen, it is essential that employees' goals and values are aligned with organization's mission and vision for creating and maintaining employee motivation.

Given changes in factors that motivate employees, the researcher supports the considerations required to be given to employees varying needs, and therefore organizations need to work towards satisfying those needs for increasing the motivation. This is supported by a study conducted by [21] with employees at a wide range of Fortune 500 and other companies. The study resulted in a model being developed on how to increase workplace motivation dramatically. The model outlines four emotional drives that underlie motivations which are depicted in Table 1. It can be concluded that managers who work towards improving employee motivation need to satisfy all the four drives which the researcher believes corresponds with Maslow's Hierarchy of Needs.

TABLE I. EMOTIONAL DRIVES

\begin{tabular}{|l|l|}
\hline \multicolumn{1}{|c|}{$\begin{array}{c}\text { Emotional } \\
\text { drives }\end{array}$} & \multicolumn{1}{c|}{ Elaboration } \\
\hline $\begin{array}{l}\text { The drive to } \\
\text { acquire }\end{array}$ & $\begin{array}{l}\text { The acquisition of scarce material } \\
\text { things, including financial } \\
\text { compensation, to feel better. }\end{array}$ \\
\hline $\begin{array}{l}\text { The drive to } \\
\text { bond }\end{array}$ & $\begin{array}{l}\text { Developing strong bonds of love, caring } \\
\text { and belonging. }\end{array}$ \\
\hline $\begin{array}{l}\text { The drive to } \\
\text { comprehend }\end{array}$ & $\begin{array}{l}\text { To make sense of our world so we can } \\
\text { take the right actions. }\end{array}$ \\
\hline $\begin{array}{l}\text { The drive to } \\
\text { defend }\end{array}$ & $\begin{array}{l}\text { Defending our property, ourselves and } \\
\text { our accomplishments. }\end{array}$ \\
\hline
\end{tabular}

Much stress is given to the different needs of employees and with this the researcher strongly believes that employee motivation is important in every organization. Ritz Carlton Hotel displays great importance on employee motivation through its management practices. The company recognizes the importance of employees to ultimate business success. Strong compensation and rewards systems are practiced as part of employee motivation which the company strongly believes would improve company profitability. The introduction of such practices has allowed the company to improve employee motivation and reduce the turnover rate from 51 percent in 1991 to slightly above 23 percent in 2004 and most importantly has helped improve work performance [14].

Further to employee motivation having an influence on the growth of an organization, a recent study by Workplace Research Foundation and University of Michigan concluded that companies with a higher level of employee motivation received a higher return on investments for shareholders in good and bad times. Companies experience higher returns each time employees' motivation increases [22]. These findings are also supported by other studies and papers, such as the article, "Putting the Service-Profit Chain to Work," published in the Harvard Business Review, which states that "people are a company's greatest asset and that a 5 percent increase in employee retention can generate a 25 to 85 percent increase in profitability" [15]. This displays the essence of identifying the factors that motivate employees and ensure that it is satisfying for continuous company progression.

Dr. Kenneth A. Kovach, professor of management at the George Mason University of Fairfax Virginia, developed a questionnaire to learn about employee motivational factors. The findings were one set of variables that would often time alter the outcomes of the rank order of Kovach's questionnaire. The factors such as age, sex, income, cultural background, and job type could be used to create subgroups [4].

The results of Dr. Kovach's study of hospitality employees' job-related motivations are:

$\begin{aligned} \text { I. } & \text { Good wages } \\ \text { II. } & \text { Security } \\ \text { III. } & \text { Opportunity for advancement } \\ \text { IV. } & \text { Good working environment } \\ \text { V. } & \text { Recognition } \\ \text { VI. } & \text { Interesting job } \\ \text { VII. } & \text { Loyalty to employees } \\ \text { VIII. } & \text { Feeling of being in one thing } \\ \text { IX. } & \text { Tactful discipline } \\ \text { X. } & \text { Sympathetic personal help }\end{aligned}$

Forty (40) years of studies revealed good wages as the fifth most important factor in motivating employees. However, this study shows that good wages is the most important factors in motivating employees. The result of the 40 years study on employee motivation is revealed in Table 2 [23]. This is similar to a study by [18] on 278 employees from 12 different hotels in the United States and Canada which found that hotel employees preferred (1) good wages, (2) job security and (3) opportunities for advancement and development. 
TABLE II. THE MOST AND LEAST IMPORTANT MOTIVATIONAL FACTORS

\begin{tabular}{|l|l|l|}
\hline Year & Most important & Least important \\
\hline 1946 & Appreciation & Discipline \\
\hline 1980 & Interesting work & Discipline \\
\hline 1986 & Interesting work & Personal problems \\
\hline 1992 & Good wages & Personal problems \\
\hline
\end{tabular}

Similarly, [24] conducted a study on employee motivation in seven Caribbean hotels and found that wages and working environment are the most important factors in motivating employees in the hotel industry.

Much has been said about the employers or rather the managers having a role in motivating employees. Contradicting to the belief of the researcher is [6] who shared that motivation is personal and internal. It cannot be directly managed; managers and employers should work on 'environmental management,' put meaning back into work and leave employees to their own motivational devices.

\section{B. Work performance}

Elton Mayo's Hawthorne studies brought employee motivation to another level with the results of the experiment on six female workers showing the impact of motivation on worker's morale and productivity which rose to higher levels. The fact that the worker's feeling of important to be able to socialize during work, a sense of belonging, secured, being recognized, and lastly a good working relationship with the management motivated them and escalated their productivity.

The results of Hawthorne have made the researcher believes the effect of motivation on work performance. The researcher believes that motivation provides the fuel for employees to deliver the desired performance in the organization. This is supported by [25] saying that motivational approaches tend to energize the workforce which improves job performance. This is in line with [26] who stresses that motivational process has an influence on job performance and other work outcomes of an individual that contributes to the employees' performance and goes further to job satisfaction.

The researcher further investigates and discovers a study conducted by [27] on incentives and motivation affecting work performance which concludes that a well designed and implemented incentive system has a positive impact on the performance of employees. Only $8 \%$ of the total respondents report that results can be achieved without incentives.

The relationship between employee motivation and work performance is further reflected in a positive reinforcement (PR) system which is based on reinforcement theory. The PR system involves the use of positive rewards to increase the occurrence of expected performance. It is based on two basic principles: 1) people perform in ways that they find most rewarding to them; and 2) by providing adequate rewards, it is possible to ameliorate performance [28]. A PR system consists of four basic steps, illustrated in the diagram below (Figure 2):

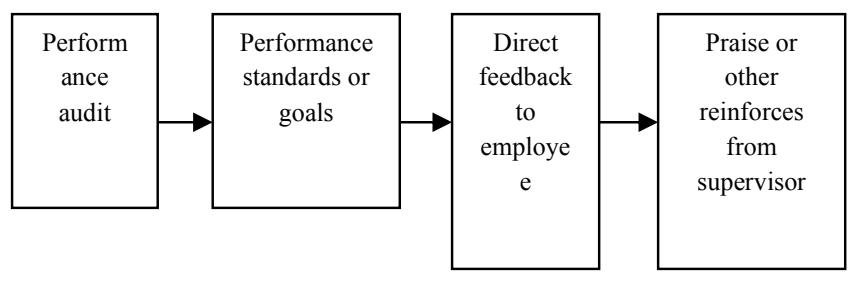

Fig. 1. : Steps in a positive reinforcement system

The system involves the use of rewards to obtain the desired performance. One of the most common rewards is money. As effective as money may be as a motivator, it can be detrimental for the organization if it is used very often. Therefore, other methods to recognize employee efforts need to be considered such as praise and recognition which need to be tied with specific job behavior. According to [28], the system encourages rewards for specific performance which should be given as soon as the desired behavior takes place. This will further motivate employees to ameliorate performance as they know their performance would lead to obtaining desired rewards. Therefore, the researcher believes that to obtain continuously desired performance, reinforcement need to be continuous through appropriate reward patterns.

According to a pool of 179 companies conducted by Total Quality and the Service Edge Newsletter, 94 percent reported having a reward and recognition program as they highly believed that employee motivation would contribute to an improvement in performance [29].

[30] conducted a study on the effect of motivation on the job performance of state government employees in Malaysia. The study discovers that there is a significant relationship between job performance and motivation. Employees with a higher level of affiliation motivation and with stronger tendency to build relationships with others tend to perform better in their job. On the other hand, some findings from studies conclude that performance is based on the choice and perception employees and it is only achievable if the skills and knowledge are suitable to the position of the employees [31].

\section{Theories of motivation}

There are numbers of popular motivational theories commonly studied and are often used by companies. Among these are Maslow's need-hierarchy theory, Alderfer's ERG theory, Herzberg's two-factor theory, Vroom's expectancy theory, Adams' equity theory, and Skinner's reinforcement theory. Maslow's need-hierarchy theory, Alderfer's ERG theory and Herzberg's two-factor theory are discussed further in this research. 


\section{RESEARCH METHODOLOGY}

This study builds on earlier researchers by various authors on the effect of employee motivation on work performance. The objective of this study is to examine and validate the influence of the five independent variables of employee motivation on work performance. This research is a combination of descriptive and inferential statistics.

\section{A. Primary Data Collection}

The primary source of data collection is through a survey questionnaire. It is administered to all individuals who are working in Malaysia Hotel industry. The primary means that the data is obtained from distributing the questionnaire directly to the individuals. The software application that is used for the analysis is SPSS (Statistical Package for the Social Sciences). The frequency test, reliability test, regression test, one-way ANOVA will be used to analyze the result of the research.

\section{B. Secondary Data Collection}

The data from secondary sources are taken to accomplish this study, especially in the area of literature reviews. The data will be obtained from textbooks, journal articles, articles, newspaper, internet resources and websites.

\section{Theoretical Framework}

The theoretical framework consists of three types of variables which are often presented in conceptual models such as interdependent, dependent and mediating variables [32]. The dependent variable is determined by the independent variable. The independent variable is the variable that can be controlled and manipulated. The mediating variable is the one that has a strong contingent influence on the independent variable - dependent variable relationship [33]. [34] defined dependent variables as a response that is affected by an independent variable. On the other hand, the independent variable is defined as the presumed cause of some changes in the dependent variable. In this study, only independent and dependent variables are used to understand the effect of five employee motivational factors on work performance.

\section{Dependent variables}

[34] defined a dependent variable as a response that is affected by an independent variable. Dependent variables are the key factors studied to understand whether they are affected by some other factors. The dependent variable focused in this study is work performance.

\section{E. Work Performance}

Work performance is the action displayed by employees during their tenure in the organization. Specific attention for this study was on the core task of employees in every department of the hotel industry. Offering a satisfactory level of customer service, maintaining cleanliness, and increasing hotel occupancy level are some of the desired work performance in the hotel industry.

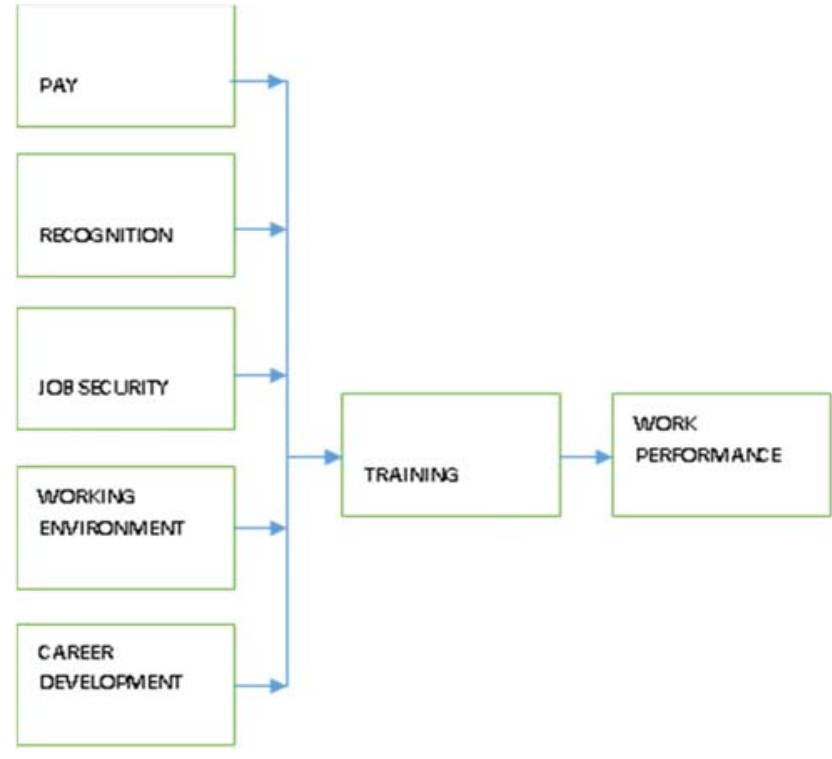

Fig. 2. Theoretical Framework

\section{F. Independent variables}

[34] defines independent variables as the presumed cause of some changes in the dependent variable. Employee motivation is an important aspect for an employee. There are many elements which contribute to it such as pay, job security, working environment, career development, and recognition. These independent variables are measured based on individual feedback through the questionnaires.

\section{G. Pay}

A fixed compensation is periodically paid to a person for regular work or services. Employees receive the pay for both physical and mental contribution to the organization. Pay is defined by The Equal Opportunities Commission as 'the ordinary basic or minimum wage or salary and any other consideration, whether in cash or kind, which the worker receives directly or indirectly, in respect of his employment, from the employer' [28].

\section{H. Job security}

Job security is an employee's confidence that they will retain in their current job. Employees with a high level of job security have a low probability of losing their jobs. Certain employments have a higher level of security in comparison to another. Sometimes job security is affected by employees' work performance and also [21].

\section{Work environment}

Work environment is the surrounding employees in which they are placed during their tenure in the organization. Therefore, the environment in which individuals are placed can affect his or her performance. Work environment can be divided into two major categories, which are (1) physical environment, which includes comfortable and safe workplace 
with ample of supporting resources and equipment; (2) social environment, which includes the relationship in organizations with other people and social systems [28].

\section{J. Career development}

Career development provide employees an opportunity to progress. Allowing employees to grow and climb the ladder of success in the organization along with increased remuneration. Acquiring new competencies and skills is part of career development as it would lead employees to a higher position. It is an entire sequence of activities and events related to an individual's career [35].

\section{K. Recognition}

Recognition is an acknowledgment of an employee's performance in the organization. It refers to the effort made by management at a company to recognize or appreciate, praise and thank employees for their contributions to the company's goals. It can be expressed in many ways, from rewards to verbal interaction. Many progressive organizations acknowledge the work of their employees through some form of recognition programs such as bonuses, training opportunities or promotion for major achievement [36].

\section{Mediating variable}

Motivational Productivity is directly based on the function of the training, with motivation and employee performance. Training helps to create a good result in performance, if training is good performance is also good. Under one condition, the training skills and development is properly performed. If the job is performed not well, employee is not motivated and at the end, the results cannot generate up to the mark. According to performance model of Blanchard, this model enables the combination of the skill and knowledge and abilities. The person does not perform well until he is not motivated.

\section{SigNIFICANCE OF STUDY}

Given constant importance on the human factor, the findings from this research would provide useful inputs to the management of hotels in Malaysia on the motivational factors; that it can contribute towards improved work performance. This study is intended to evaluate the factors that motivate employees in Malaysia Hotel industry. It would help to realize the importance of effective employee motivation and its effect on employees' work performance. The researcher also believes that the findings of this research would greatly contribute to the tourism industry in Malaysia, given the government's constant effort of making Malaysia a famous tourism spot. The government has recognized the importance of the workforce of the hotel industry and the findings of this research would offer great inputs on ways to keep the workforce motivated for improved performance.

\section{CONCLUSION}

The ultimate aim of the research is to discover and examine the significant factors that could influence work performance. This study also can be a great help for the government and tourism ministry as they are striving and findings way to keep employees motivated in order to improve the tourism industry. It provides an insight that the workforce is looking for more than just monetary rewards to keep them motivated to perform in the hotel industry. Based on a systematic review and content analysis of the articles, this research is able to outline the relationship between employee motivation and work performance in the literature reviewed.

\section{Acknowledgment}

I would like to take this opportunity to thank those people who spent their time and shared their knowledge for helping me complete my thesis with the best possible result. First of all, I wish to express my appreciation and thanks to Dr.Mohammad Yazam Sharif, the research co-author for his vigilant supervision, invaluable assistance, guidance and share of his experience throughout this research assignment.

My special thanks to my parents and family. Last but not the least, big thanks and sincere appreciation to my postgraduate colleagues.

Thank you very much.

\section{References}

[1] M.N.H., Mazumder, Does tourism contribute significantly to the Malaysian economy? Multiplier analysis using I-O technique. International Journal of Business and Management. 4(7), 2009, pp 146 $-159$

[2] K.W., Awang, N.K.Ishak, S.M., Radzi \& A.Z., Taha, "Environmental variables and performance: Evidence from the hotel industry in Malaysia". International Journal of Economics and Management. 2(1), 2008, pp59- 79

[3] J., Chan, Awards night to honor employees of hotel industry [Online] The Star, 2011

[4] K. A., Kovach, "What motivates employees? Workers and supervisors give different answers". Business Horizons. 1987, pp 58-65.

[5] S. Barda, "10,000 Jobless So far Since Jan 1". The Star February, Jan 2015.

[6] J., Morgan, "Employee motivation: Staff looking for incentives and recognition scheme "[Online], 2011

[7] N. Foon, "Malaysia's Tourism Sector losing employees to other Countries". News Straits Times, 02 July 2007.

[8] Datuk Seri Tengku Adnan Tengku Mansor, "Shortage of locals forcing Hospitality Industry to hire Foreigners". The Star, July 2007.

[9] N.R. Lussier. Human Relations in Organizations: Applications and Skill Building, New York: McGraw-Hill, 2008.

[10] Y.T. Chew, "Achieving organizational prosperity through employee motivation and retention: A comparative study of strategic HRM practices in Malaysian institutions". Research and Practice in Human Resource Management, 13(2), 2005, pp 87-104.

[11] S., Kamali, B., Khan, M.B., Khan, \& A.B., Khan, Motivation and its impact on job performance, 2006. 
[12] P. Janes, \& M. Wisnom, Changes in tourism industry quality of work life practices. Journal of Tourism Insights. 1(1), 2011, pp $107-113$

[13] J. Kempton, Human Resource Management and Development. Current Issues and Themes. New York: Macmillan Press Ltd, 1995.

[14] S.P., Robbins, and M., Coulter, Management. 7th Ed. London: Prentice Hall, 2005.

[15] I., Ozer, Intrinsic motivation - The missing link in many incentive programs [Online] Selfgrowth.com, 2011

[16] A., Dysvik, and B., Kuvaas, Exploring the relative and combined influence of mastery-approach goals and work intrinsic motivation on employee turnover intention. Personnel Review. 39(5), 2010, pp $622-$ 638

[17] S.J., Condly, Shedding light on the mystery of motivation - Incentive research foundation [Online] 2006, Incentive research foundation

[18] C.F., Chiang, \& S., Jang, An expectancy theory model for hotel employee motivation. Abstract only [Online], 2007

[19] K.W., Thomas, Intrinsic motivation at work: Building energy and commitment. San Francisco: Berrett-Koehler Publishers, 2000.

[20] S., Karimi, Why is motivation important?, 2011, [Online] ehow Available at: http://www.ehow.com/about_4579837_motivationimportant_html

[21] N. Nohria, B., Groysberg, \& L.E., Lee, Employee motivation: A powerful new model [Online] Harvard Business Review, 2008.

[22] D., Serchuk, Shareholders win when employees are motivated [Online] Forbes, 2009

[23] C., Wiley, "What motivates employees according to over 40 years of motivation surveys". International Journal of Manpower. Volume 18, No3, Dec 2014, pp $263-280$.
[24] K. Charles, and L.Marshall, "Motivational Preferences of Caribbean Hotel Workers: An Exploratory Study". International Journal of Contemporary Hospitality Management, 4 (3), 1992, pp.25-29

[25] W., Byham, \& R.,Moyer, Using Competencies to Build a Successful Organization [Online], 2005

[26] C., Strain, Need for Autonomy as a Moderating variable in the Model of the Determinants of Salesperson Performance. [Online], 1995.

[27] H.D., Stolovitch, Incentives, Motivation and Workplace Performance: Research and best practice, Nov 2014.

[28] R.S., Schuler, Managing Human Resources. 6th Ed. United States: International Thompson Publishing, 1998.

[29] A. Sherman, G. Bohlander, \& S. Snell, Managing Human Resources. 10th Ed. United States: International Thompson Publishing, 1996

[30] F.,Salleh, Z.,Dzulkifli, W.A.W., Abdullah, and N.H.M., Yaakob, The effect of motivation on job performance of state government employees in Malaysia. International Journal of Humanities and Social Science. 1(4), 2011, pp 147 - 154

[31] R., Christensen, \& B., Wright, The effects of public service motivation on the job choice decisions: exploring the contributions of personorganization fit and person-job fit [Online], 2009.

[32] D.R., Cooper, and C.W., Emory,. Business Research Methods. Chicago: Richard D. Irwin, 1995.

[33] U., Sekaran Research methods for business: A skill building approach. NewYork: John Wiley \& Sons, Inc. 2000.

[34] S.P., Robbins, Organizational Behavior, 8th Ed. London: Prentice Hall, 1998.

[35] B.K., Bhatia, Career development of employees [Online] Emp track, 2010.

[36] K., Eskridge, What is recognition? [Online] Humans at work, 2009 